
July 1936

\title{
OXIDATION OF WOOL: PHOTOCHEMICAL OXIDATION ${ }^{1}$
}

\section{By Arthur L. Smith and Milton Harris ${ }^{2}$}

\section{ABSTRACT}

The photochemical decomposition of wool has been investigated. The deterioration, as evidenced by the decrease in cystine content and the increase in alkali-solubility, ammonia nitrogen, and sulfate sulfur, is accelerated by acids and decelerated by alkalies. The extent to which wool is degraded during irradiation is directly proportional to the decrease in cystine content and to the increase in alkali-solubility.

The sulfur content of untreated and of acid-treated wool decreased during irradiation. The data suggest that a portion of the sulfur in wool is converted to hydrogen sulfide, some of which is subsequently oxidized to sulfuric acid.

I. Introduction _.

II. Materials and methods

III. Results and discussion 98

IV. References.

\section{INTRODUCTION}

The photochemical decomposition of proteins, carbohydrates, fats and many nitrogenous substances is an oxidation process which is accelerated by acids and decelerated by alkalies $[1,2,3,4,5,6,7] .^{3}$ In the case of proteins and other nitrogenous materials, this oxidation process is generally accompanied by the cleavage of ammonia $[2,3,4]$. In earlier studies on the photochemical decomposition of silk [1, 2], it was shown that the amount of this ammonia is a measure of the extent to which silk is damaged by exposure to light $[1,2]$.

Wool, which is relatively more stable to light than silk [8], is also oxidized during irradiation. The reaction, however, appears to be of a somewhat different nature, owing to the inherent differences in chemical constitution of the two proteins. The chief point of attack appears to be the disulfide group of the amino acid, cystine, which is present in wool but not in silk. This group is readily attacked by oxidizing agents and becomes more susceptible to the action of alkalies $[9,10]$. The extent to which the wool is oxidized bears a functional relationship to the decrease in its cystine content and to the increase in the alkali-solubility of wool.

The present investigation was undertaken to extend our observations on reactions involving the disulfide group in wool and to determine the effect of irradiation on the sulfur and nitrogen in wool protein.

1 This is the third paper of a series on studies relating to the oxidation of wool.

${ }^{2}$ Research associates at the National Bureau of Standards representing the American Association of Textile Chemists and Colorists.

3 The numbers in brackets here and elsewhere in the text refer to the numbered references at the end of this paper. 


\section{MATERIALS AND METHODS}

The wool used in these experiments was worsted top and worsted yarn, each of which had been purified by extraction with alcohol and ether and finally washed with distilled water. The wool was placed in thin layers on cardboard strips and held in place by clips at each end. The samples were exposed to the radiation of a glassenclosed carbon arc ${ }^{4}$ for definite periods of time. The distance from the axis of the arc to the wool was 10 inches.

The alkali-solubility was determined by a method previously described [9], the cystine content by the Sullivan method [11], the sulfate sulfur by the method of Mease [12] and the sulfuric acid by the pyridine method [13]. Ammonia nitrogen was determined by measuring that portion of the nitrogen which is liberated when the wool is boiled in a saturated solution of magnesium oxide. All data are calculated on the basis of the dry weight of the wool.

\section{RESULTS AND DISCUSSION}

The effect on worsted top wool of exposure to the radiation for different lengths of time up to 100 hours is shown in table 1 . The alkali-solubility, ammonia nitrogen and sulfate sulfur increase and the cystine content decreases with increasing time of exposure. The values in the last two columns of table 1 are of special interest since they not only show that sulfuric acid is formed during exposure, but also that practically all the sulfate in the exposed wool is in the form of sulfuric acid. The formation of acid in irradiated wool has been previously noted or suggested by several investigators [14, 15, 16, 17] but only Von Bergen [18] actually demonstrated the presence of sulfuric acid.

TABLE 1.-Effect on wool top of exposure to the radiation from a glass-enclosed carbon arc for different lengths of time

\begin{tabular}{|c|c|c|c|c|c|c|}
\hline Sample & $\begin{array}{c}\text { Duration of } \\
\text { exposure }\end{array}$ & $\underset{\text { bility }}{\text { Alkali-solu- }}$ & Cystine & $\begin{array}{c}\text { Ammonia } \\
\text { nitrogen }\end{array}$ & $\begin{array}{l}\text { Sulfate } \\
\text { sulfur }\end{array}$ & $\begin{array}{l}\text { Sulfuric } \\
\text { acid sulfur }\end{array}$ \\
\hline $\begin{array}{l}1 \\
3 \\
4 \\
4 \\
5\end{array}$ & $\begin{array}{r}\mathrm{hr} \\
0 \\
5 \\
15 \\
30 \\
50 \\
100\end{array}$ & $\begin{array}{l}\% \\
11.9 \\
14.5 \\
17.2 \\
21.9 \\
32.2 \\
36.2\end{array}$ & $\begin{array}{r}\% \\
12.2 \\
11.9 \\
11.1 \\
10.4 \\
8.6 \\
7.9\end{array}$ & $\begin{array}{r}\mathrm{mg} / \mathrm{g} \\
0.28 \\
.21 \\
.71 \\
.68 \\
1.22\end{array}$ & $\begin{array}{r}\% \\
0.06 \\
.07 \\
.22 \\
.25 \\
.37\end{array}$ & \begin{tabular}{|c|}
$\%$ \\
0.21 \\
.34
\end{tabular} \\
\hline
\end{tabular}

In figure 1 , the increase in the alkali-solubility is shown to be directly proportional to the decrease in the cystine content. While previous work $[10,11]$ indicated a relationship, this is the first case in which it was found to be linear.

The effect of acid and alkali on the photochemical deterioration of wool was also investigated. Six-gram samples of wool yarn were soaked in $0.1 \mathrm{~N}$ solutions of hydrochloric acid and in sodium carbonate solutions of the same strength for 15 minutes at room temperature, centrifuged, and dried in an atmosphere of 65 -percent relative humidity at a temperature of $70^{\circ} \mathrm{F}$. Samples of untreated and of acid-

- Fade-Ometer, type F.D.A., Atlas Electric Devices Co., Chicago, Ill. 
and alkali-treated yarns were exposed to the radiation for 100 hours. The effect of the exposures is shown in table 2. The deterioration of the wool, as shown by the decrease in the cystine content and the increase in the alkali-solubility and the ammonia nitrogen content, is greater in the acid-treated and less in the alkali-treated samples than in the untreated samples.

TABLE 2.-Effect on untreated, acid-treated, and alkali-treated wool of exposure to the radiation from a glass-enclosed carbon arc for 100 hours 1

\begin{tabular}{|c|c|c|c|c|c|c|c|}
\hline Treatment & $\begin{array}{l}\text { Total } \\
\text { sulfur }\end{array}$ & $\begin{array}{l}\text { Total sulfur } \\
\text { after pyri- } \\
\text { dine ex- } \\
\text { traction }\end{array}$ & $\begin{array}{l}\text { Sulfate } \\
\text { sulfur }\end{array}$ & $\begin{array}{l}\text { Sulfuric } \\
\text { acid sul- } \\
\text { fur }\end{array}$ & $\begin{array}{l}\text { Cystine } \\
\text { sulfur }\end{array}$ & $\begin{array}{l}\text { Alkali- } \\
\text { solubil- } \\
\text { ity }\end{array}$ & $\begin{array}{c}\text { Ammonia } \\
\text { nitrogen }\end{array}$ \\
\hline $\begin{array}{l}\text { Untreated and unexposed... } \\
\text { Untreated and exposed } \\
0.1 \mathrm{~N} \text { hydrochloric acid.-.-.- } \\
0.1 \mathrm{~N} \text { sodium carbonate.-... }\end{array}$ & $\begin{array}{l}\% \\
3.61 \\
3.43 \\
3.35 \\
3.65\end{array}$ & $\begin{array}{l}\% \\
3.25 \\
3.30 \\
3.29\end{array}$ & $\begin{array}{l}\% \\
0.02 \\
.24 \\
.14 \\
.24\end{array}$ & $\begin{array}{r}\% \\
0.01 \\
.27 \\
-\end{array}$ & $\begin{array}{l}\% \\
3.40 \\
1.92 \\
1.66 \\
2.21\end{array}$ & $\begin{array}{l}\% \\
11.6 \\
53.0 \\
67.8 \\
47.7\end{array}$ & $\begin{aligned} \mathrm{mg} / \mathrm{g} \\
0.36 \\
1.65 \\
2.24 \\
1.48\end{aligned}$ \\
\hline
\end{tabular}

1 These exposures were made on a different Fade-Ometer and the results of these experiments are not strictly comparable with those recorded in table 1.

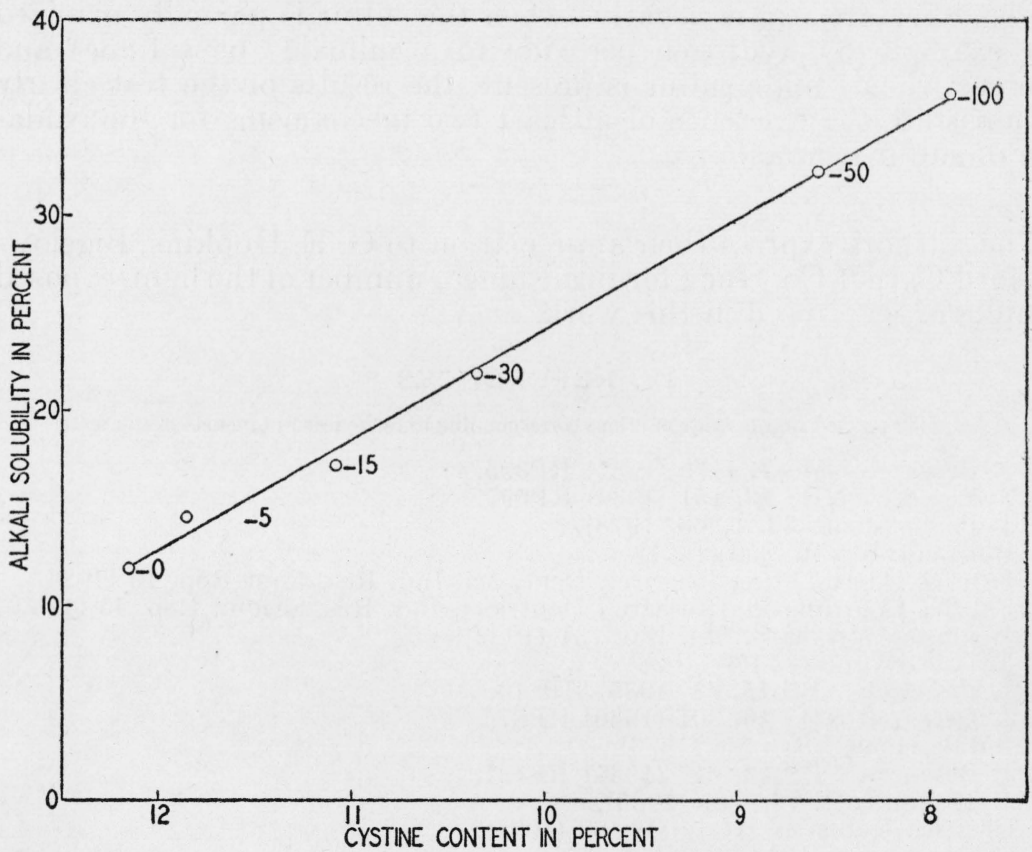

FigURe 1.-Relationship between the cystine content and the alkali-solubility of wool exposed to the radiation from a glass-enclosed carbon arc.

The figures on the curve represent the duration of exposure, in hours.

The total sulfur content of the untreated and the acid-treated samples decreased during exposure. This suggests the possibility that irradiation converts a portion of the sulfur in wool to a volatile form, for example, hydrogen sulfide. Hydrogen sulfide is readily oxidized to sulfuric acid, which would account for the comparative ease with 
which some of the disulfide sulfur in wool is converted to sulfate sulfur. In view of the great difficulty with which even small amounts of sulfur in wool are oxidized to sulfate by oxidizing reagents $[19,20]$, the ease of oxidation of sulfur to sulfate by irradiation cannot be emphasized too strongly. It should be noted that while the total sulfur and sulfate sulfur contents of the alkali-treated sample are higher than those of the acid-treated sample, the total sulfur after extraction of the wool with pyridine is the same for both samples. These results are also readily explained on the assumption that hydrogen sulfide is formed as an intermediate product. It is obvious that the hydrogen sulfide would be volatile in the presence of acids but would react with alkali to form a nonvolatile compound.

The experimental results reported in this paper indicate that althougb the photochemical decomposition of wool involves an oxidation reaction, the mechanism of the reaction is very different from that of such oxidizing reagents as hydrogen peroxide. ${ }^{5}$ Further evidence supporting this is obtained by subjecting the exposed samples to the lead acetate test, described by the authors elsewhere [20]. The irradiated samples all gave strong positive reactions, indicating the presence of sulfide sulfur. Since it has previously been shown that the lead acetate test is negative when the sulfur is partially oxidized (for example by hydrogen peroxide to a sulfoxide or sulfone) and positive when sulfide sulfur is present, the results of the test clearly demonstrate the existence of at least two mechanisms for the oxidation of sulfur in wool.

The authors express their appreciation to G. E. Hopkins, BigelowSanford Carpet Co., Inc., for furnishing a number of the light-exposed samples of wool used in this work.

\section{REFERENCES}

[Bracketed numbers are citations corresponding to references in brackets in the text]

[1] J. Research NBS \%, 1179 (1931) RP395.

[2] J. Research NBS 13, 151 (1934) RP697.

[3] J. Phys. Chem. 32, 1,263 (1928).

[4] Biochem. Z. 239, 250 (1931).

[5] Fabrics Coordinating Research Dept. Sci. Ind. Res. First Rep. 10 (1926).

[6] Fabrics Coordinating Research Dept. Sci. Ind. Res. Second Rep. 95 (1930).

[7] Wyoming Agr. Exp. Sta. Bus. 131 (1922).

[8] Textile World 14,159 (1928).

[9] J. Research NBS 15, 63 (1935) RP810.

[10] J. Research NBS 16, 301 (1936) RP875.

[11] Public Health Rep. 86 (1930).

[12] J. Research NBS 13, 617 (1934) RP731.

[13] J. Textile Inst. 26, T87 (1935).

114] Chimica Industria (Italy) 1\%, 82 (1935).

[15] Compt. Rend. 183, 596 (1926).

[16] Textile Argus 7, 753 (1930).

[17] J. Textile Inst. 2\%, T25 (1936).

[18] Melliand Textile Monthly 2, 9 (1930).

[19] J. Biol. Chem. 110, 343 (1935).

[20] J. Research NBS 16, 309 (1936) RP876.

Washington, May 16, 1936.

$\checkmark$ The available data do not warrant suggesting at this time a specific mechanism for the action of light on the cystine in wool. Experiments now in progress indicate that the first step is a splitting of the disulfide group, accompanied by the liberation of hydrogen sulfide, whereas in oxidation with hydrogen peroxide intermediate products of the sulfoxide, sulfone, etc., types are formed. 